\title{
Gamification in School Libraries
}

\section{Dejan Šiptar}

dejan.siptar.kr@gmail.com

Josip Badalić Primary School in Graberje Ivanićko, and Ludina Primary School in Velika Ludina

Keywords: gamification, ICT tools, new teaching models, practical examples

\begin{abstract}
This paper deals with the topic of applying the concept of gamification in the educational process. The definition of the concept is presented, as well as its description and application. The second part of the paper presents several ICT tools, which can aid in applying gamification in the classroom environment, as well as offers suggestions for activities using these tools.
\end{abstract}

\section{Introduction}

For the past few centuries, the existence of libraries has been marked by change and adaptation. Since the early days, when they basically served as exclusive repositories, societal changes and users' needs impelled them to open themselves to the public and offer their content to everyone. Further development turned them into educational centres for their communities. The development of technology added a multimedia level. Prompted by that same technological development, we continue to adapt to this very day by digitising content and providing access to databases.

However, the change in technology has caused a change in society as well, including our users. The fact that this change is all-encompassing, extending to all types of users, has been felt by school librarians as well. Today's pupils are born in the digital world. Technology is available to them at every step since before they take their first literal one. The parents will quite often provide their very young children with smartphones, tablets, and personal computers in order for them to play or watch amusing content. By the time they start their schooling, these children are so used to digital tools they find little interest in books, magazines, posters and printed exercises which provide little to no interaction options. Moreover, you can say that for the current generation of pupils video games represent a significant cultural medium and source of formative experiences. Just as the previous generations experienced the same with literature, film and television (Deterding et al., From Game Design Elements to Gamefulness, 2011).

School librarians encounter a major problem here, especially when teaching information literacy to younger pupils where they primarily have to focus on physical copies of reference material, books and magazines. The following question presents itself: how to introduce library material which does not require technology to pupils who are best motivated by fun and interaction provided by technology? The answer can be found in ICT tools, gamification and the librarian's creativity. 


\section{Definition}

When defining gamification it is necessary to make the distinction between game and play (Deterding et al., From Game Design Elements to Gamefulness, 2011). Having our pupils play during an activity does not mean we are implementing Gamification. We can define any activity a participant finds fun as playing. An important factor in playing is the fact that it does not contain structured rules, a goal, nor purpose, besides fun. If we watch two dogs chasing each other in the park we will say they are playing. Their activity does not have structured rules nor a previously defined ending. The same goes for many activities children partake in at an early age. Toddlers will run after their parents or each other purely for the fun of the activity. As they grow, they will gradually start turning this playing into a game by adding rules. The goal will become to catch the other player, then reverse roles. In time they will start adding additional rules; time and space limitations (you have 1 minute to catch me, but we can't go outside the fence), points, awards. With these additions the concept changes and the play becomes the game. The activity remains fun but is accompanied by elements which structure it, focus it, define its goal and ending, and add points and, ultimately, present a winner. It had been added by rules and a competitive aspect i.e. the aspiration towards reaching certain goals or outcomes (Deterding et al., From Game Design Elements to Gamefulness, 2011).

Now we arrive to the definition of the concept of gamification, which varies from author to author. The same author even defines it differently in different papers. Brian Burke redefines gamification as "the use of game mechanics and experience design to digitally engage and motivate people to achieve their goals" (Burke, 2014). I find this definition limiting because of the term digitally. The reason for it can be found in several definitions provided by a group of authors headed by Sebastian Deterding. Several years before Burke they defined gamification as "the use of game design elements in non-game contexts" (Deterding et.al., From Game Design Elements to Gamefulness, 2011; Deterding et.al. Gamification: Toward a definition, 2011). In their other paper they expand the definition by adding “...to improve user experience [...] and user engagement" (Deterding et.al. Gamification: Using Game Design Elements in Non-Gaming Contexts, 2011). With this addition the definition comes closer to the one provided by Burke, but its basis significantly differs by not requiring a digital element in order to classify something as gamification. Deterding and his co-authors never mention the usage of digital tools as being necessary in order to gamify an activity. Some gamification elements they list include badges, leader boards, levels, time constraint, turns and clear goals (Deterding et. al. From Game Design Elements to Gamefulness, 2011). None of these elements require the implementation of digital technology. A perfect example of this are board games, which implement many gamification elements, including the ones listed without the use of digital technology.

The fact, however, remains that we currently find ourselves in a digital age. We find digital technology in almost all aspects of our daily lives and its application has become quite common. Moreover, especially with children, it appears that activities which do not include digital technology are perceived as less interesting and outdated. As far as gamification goes, the application of digital technologies can be of great use to the user and help him or her implement gamification into his or her activities. There already exists a huge variety of easily accessible online apps designed with the purpose to gamify educational activities. 


\section{Tools}

\section{Quiz, Making Tools}

Socrative (https://www.socrative.com/) is a tool in which pupils solve a quiz previously created by their teacher or librarian. The pupils solve it in real time, each using his computer or tablet, or they can solve it in groups. The tools' special characteristic is that you can follow the pupils' progress on the main screen, either by showing a table containing all the questions and participating pupils, as well as their progress and score; or by showing an animation depicting the progress of the individual pupil or group. The latter is especially interesting to pupils because the animation takes the form of a race and pupils can follow their progress the entire time, as well as the progress of other contestants. When the activity is done the teacher or the librarian can analyse all the answers provided by the pupils for each individual question and discern which topic needs to be additionally worked on.

Kahoot! (https://kahoot.com) is a quiz making tool which, unlike Socrative, measures and gives points for the time it took for a pupil to answer the question, thus awarding him or her for quick thinking, if the answer was correct, of course. The questions and up to four possible answers are presented on the main screen, while the screen on the pupils' devices only shows symbols related to the offered answers. So, the pupils have to carefully follow the main screen. After every question the pupil is given feedback on whether his answer was right or wrong, and the main screen shows a leader board of five pupils with the most points. The benefit of this is that the last places are not shown, thus keeping pupils with little points equally motivated to continue participating. Kahoot! provides a very fast and energetic activity which quickly engages pupils, and is most suited for individual work, but can be used with groups as well.

Quizziz (https://quizizz.com/) is a tool very similar to Kahoot!, with a couple of minor, but important differences which a teacher or a librarian can find more suitable to his or her work. Pupils use this tool to solve quizzes, but they are not required to pay attention to the main screen. They can solve it in real time, in which case the results and leader board will be presented on the main screen, but all the questions and the selection of answers will be presented on the screen of the device they are using. Additional entertaining element is provided by an amusing image (often in the form of a meme) which they will get to notify them whether their answer was correct or not. However, these quizzes do not need to be solved in real time. The teacher or librarian can start a quiz and instruct the pupils on how to solve it from home. After a given time limit the quiz will no longer be available, and the teacher or librarian will be able to analyse the pupils' results.

\section{Class Management Tools}

ClassDojo (https://classdojo.com) is a tool in which the librarian or teacher can create the class or group of pupils he or she is working with. Each pupil will be represented by a character in the form of a colourful whimsical monster. The tool can be used to mark attendance and pupil activity by giving and taking away points. The tool also functions as a closed and controlled social network which can be accessed by pupils and parents from home in order to follow classroom activities and communicate to each other. It is important to note that this virtual surrounding, unlike other social networks, is completely closed to the public and can only be accessed by people who were given access by the teacher or librarian who created the virtual classroom. This makes it a safe online space for pupils, and the teacher or librarian can easily supervise their activity. This tool is especially useful to schools which have not implemented an online pupil registry, as it can provide parents with insight into their child's school activities and results from home. 
Classcraft (https://www.classcraft.com) is another classroom management tool; however, this one is additionally enriched with a theme. The librarian or teacher will once more create a character for each of his pupils, but this time the setting will be that of fantasy, sword and sorcery. Each character will be presented as a warrior, wizard or cleric, with a wide range of personalising elements. Each pupil will also choose a skill available only to his or her character, which can also be applied in the classroom environment. As pupils partake in classroom activities, the teacher or librarian awards them with experience points. When they collect enough points, their character will be able to level up and chose another skill. In case they do not participate in classroom activities, health points will be taken away from them, which will make their characters weaker. This is the part where the skills chosen previously come in handy and can enable positive interaction among pupils. The warrior has the skill to redirect damage to himself and can thus prevent one of his classroom colleagues from losing health points. Clerics, on the other hand, can heal characters and retrieve lost health points. The more successful the pupils are, and the more experience points they collect, the wider choice of skills is presented to them, some of them even enabling them to leave the classroom for five minutes. The tool also provides learning scenarios in which pupils participate in a learning activity presented as a quest and gather experience points through solving tasks.

\section{Other Useful Tools}

LearningApps (https://learningapps.org) is a tool that enables the user to create a large variety of interactive apps. Quizzes, crossword puzzles, hangman, word searches, pairing tasks, puzzles, Who wants to be a Millionaire, are only some of the provided options. All the user needs to do is to incorporate his or her content into one of the chosen apps. They will then be provided with a link they can embed into their school or library webpage. All the pupils need to do is visit the page and they can partake in the activity. The tool also provides a QR code which can also be printed out or embedded. In both cases the pupils are partaking in the activity in a safe online environment without risk of being exposed to inappropriate content.

Plickers (https://www.plickers.com) is another quiz making tool, but the manner of pupil participation differs greatly from the previous two. The librarian or teacher uses the tool to create the quiz. They then use it to print out squares with varyingly edged sides for each pupil (the tool can be used to monitor which square was given to which pupil by name). Each side of the square represents a letter, A, B, C or D. The teacher or librarian will start the quiz on the main screen and on it the pupils will be able to see questions with four answers provided. On their squares they chose the side marked with the letter they consider representing the correct answer and point that side of the square up. The teacher or librarian then uses the Plickers smartphone app to scan the squares, and the results are automatically presented on the main screen.

\section{Application}

So how can school librarians apply gamification in their work with pupils? There are many possibilities and they all depend on the librarian's creativity. A simple, and no less effective than others, example would be the following. If we wanted to teach our pupils how to use encyclopaedias and encourage them to do research, we could turn the lesson into a competition. We divide pupils into groups, show them how to use the index, and then give them search words they need to find as fast as they can. The lesson will be dynamic, and the competition element will encourage them to actively participate.

The next step would be to add the digital element our pupils are so exposed to as motivation. Using interactive ICT tools, we meet our pupils halfway by creating activities containing digital technology. A

International Association of School Librarianship

https://iasl-online.org 
very important component here is the librarian's creativity to create an activity that does not require the pupils to constantly stare at the screen but encourages them to move around and search for information from physical sources placed in the classroom or library. Adapting the previous encyclopaedia example with this would give us the following activity: using online quiz tools like Socrative, Kahoot! or Plickers we would create tasks for the pupils, and they would have to use those tools to perform those tasks; they have to find the answers in the copies of encyclopaedias available in the library and put the answers into the tools we are using. What we have got are doubly motivated pupils, on the one hand by technology and interaction, and on the other by playful competition.

Classroom management tools like Classcraft and ClassDojo can function as an e-register, especially useful for school librarians who are not required to grade their pupils for their activities. If you have a group of pupils you often work with, you can create it in one of those tools. Use the tool when working with them in order to mark their activity in your lessons. The theme, the entertaining animations and points will help create an interest in your activities and encourage them to participate.

LearningApps and Quizizz enable creating content which will be available to pupils from their homes. Thus encouraging them to solve educational tasks in a digital environment in their leisure time. Quizizz will also provide you with feedback you can use to further plan your work.

Of course, teachers and librarians are not expected to use all of these tools in their work. However, by applying only one, you provide pupils with a different form of teaching (and learning) and encourage them to participate in your activities, resulting in improved acquisition of content. Gamification's greatest advantage is that, besides making it fun, it adds an emotional component into the learning process, which is a very important element for the improvement of learning.

\section{Conclusion}

Gamification is a concept which is becoming more present in various fields. From production to finance, health, and even sustainable development (Deterding et al., From Game Design Elements to Gamefulness, 2011). Some board game societies in Croatia offer team building sessions in order to improve the quality of the working environment, learning about risk taking and responsibility, and encouraging team work and communication (Udruga igranje, 2019).

This concept acknowledges the importance of the affective approach of the individual towards task fulfilment, and the effect such an approach has on the outcome of the task, as well as the individual. It is especially applicable in the educational context, where we quite often encounter a lack of motivation among our pupils to participate, as well as lack of interest in many topics they encounter. By changing the method, especially by using ICT tools, we meet them half-way and provide them with activities most of them partake in in their leisure time. The atmosphere we create is competitive and lively, and the feedback is instantaneous. An interesting activity will attract them to a topic they do not find interesting, and the affective approach will help reach positive outcomes and skill learning.

It is also very important to consider children's dependency and addiction to digital technologies, and make sure our activities are not only comprised of an hour of them staring into a screen. Activities on the computer can easily be mixed with activities in the classroom, especially when teaching information literacy, which often requires using sources like reference material, magazines and books. The tasks can be given in one of the tools while the answers can be found in books. During the lesson the pupils will be

International Association of School Librarianship

https://iasl-online.org 
active, and they will use several different information sources, thus improving both their information and computer literacy at the same time, as well as social skills during group work.

Finally, probably the best and most important element of the concept of gamification is the fact that it is not limited to exclusive use of digital tools. A creative and diligent librarian or teacher can create a gamified activity containing all game elements listed at the beginning of this paper without a single digital component. This wide palette of opportunities represents the essence of the beauty of gamification. Its applicability, adaptability and potential are means we can easily use to become better connected to our pupils and make the learning process more fun and more effective.

\section{REFERENCES}

Burke, B. Gartner redefines gamification. [Online] 2014, https://blogs.gartner.com/bri an_burke/2014/04/04/gartner-redefines-gamification/ (accessed July 23, 2019).

Deterding, S. ; Dixon, D. ; Khaled, R. ; Nacke, L. From game design elements to gamefulness: Defining "Gamification". MindTrek'11 Proceedings of the 15th International Academic MindTrek Conference: Envisioning Future Media Environments. [Online] 2011, 9-15. http://ww w.hubscher.org/roland/courses/hf765/readings/Deterding_2011.pdf (accessed July 23, 2019).

Deterding, S. ; Khaled, R. ; Nacke, L. ; Dixon, D. Gamification: Toward a definition. CHI Gamification workshop proceedings. [Online] 2011, http:/gamification-research.org/wp-content /uploads/2011/04/02-Deterding-Khaled-Nacke-Dixon.pdf (accessed July 23, 2019).

Deterding, S. ; Sicart, M. ; Nacke, L ; O’Hara, K. ; Dixon, D. Gamification: Using game design elements in non-gaming contexts. CHI'11 Extended Abstracts on Human Factors in Computing Systems. [Online] 2011, 2425-2428. http://gamification-research.org/wp-content/uploads/2011/04/01-D eterding-Sicart-Nacke-OHara-Dixon.pdf (accessed July 23, 2019).

Udruga Igranje. Team building uz igranje modernih društvenih igara. [Online] 2019, https://igranje.hr/team-building (accessed July 23, 2019).

\section{Biographical Note}

Dejan Šiptar received his MA in English Language and Literature, Comparative Literature, and Library Sciences from the Faculty of Humanities and Social Sciences in Zagreb. He has been working as a school librarian since 2011 and currently works in Josip Badalić primary school in Graberje Ivanićko, and Ludina primary school in Velika Ludina. In 2016 he participated in an eTwinning seminar on gamification which took place in Vilnius, Lithuania. Since then he has been applying gamification in his work with his pupils and holding workshops in national school librarian conferences and meetings. In 2018 he won the "Artefakt" award for best short story in the category of science fiction for the story It's all right published in the short story collection Homo Climaticum. 